Engammare, Max, Pasteur Philippe Fromont, Marie-Christine GomezGéraud, and Michel Grandjean.

Castellion à Vandoeuvres (1515-2015).

Geneva: Droz, 2017. Pp. 92. ISBN 978-2-600-04764-7 (paperback) CHF 22.

This volume contains four conference papers that were delivered at the Jubilee marking the five-hundredth anniversary of Castellion's birth that was held in Vandoeuvres, France. These papers analyze different aspects of this religious thinker, and aim to show how Castellion's thought is relevant to the present time. The four authors-Marie-Christine Gomez-Géraud, Max Engammare, Michel Grandjean, and Philippe Fromont-are all specialists on Castellion; their book seems intended for any student of this prolific sixteenth-century theologian. It is complemented by an index of the names used in the volume and of the works of Castellion.

The introduction, written by Pastor Vincent Schmid, talks about the Jubilee as a way of rectifying the fact that virtually no celebration of Sebastien Castellion had ever before taken place. Schmid then traces the relationship between John Calvin and Castellion until the controversy surrounding Michel Servet's death. He continues by talking about the subject's spirit of tolerance and peace, and finishes by underlining the significance of Castellion's thought for the times in which we live. Castellion, in other words, deserves to be heard in an age marked by religious absolutism. Schmid's comments on the articles are interspersed between paragraphs in his survey of Castellion's life.

The first article, by Gomez-Géraud, focuses on Castellion's translation of the Bible into everyday French: La Bible nouvellement translatée. She starts by discussing Castellion's humanism and his translations in this vein. In her study of Castellion's biblical translations, she begins with the Moses latinus: Castellion's Latin translation of the Pentateuch. She shows here that his translation was more philological than spiritual. Next, she discusses La Bible nouvellement translatée. Here, she analyzes three of Castellion's characteristics as its translator: teacher, writer, and believer. She establishes one way in which Castellion made difficult words understood in this Bible: neologisms. She also notes that Castellion's translation brought the text alive through its vivaciousness. She finishes by touching on the fact that Castellion was not an ivory tower intellectual: he was involved in the world. His translation of the Bible into everyday French is proof of this. 
The second contribution in this collection is by Engammare. Here, he discusses the possible ways in which Castellion considered the relationship between church and state. According to Engammare, Castellion-whose ecclesiology was not very well developed-did not believe that Christians should be punished because of their religious beliefs. Engammare further underlines that the true heretic for Castellion was the person who sinned against the natural law present in all of us-for example, a blasphemer-and not a Christian whose opinion differed from another's; according to this sixteenth-century thinker, a judge could sentence a person who blasphemed to death. Engammare concludes with a quote by Castellion himself which shows that at the heart of Castellion's logic concerning the interference of the church in matters of State was the belief that it was not possible to be absolutely right about religious doctrine. Finally, in the annex to this article are possible hypotheses as to the meaning of Castellion's pseudonyms.

Michel Grandjean, in the third article, discusses the question of whether or not Castellion was our contemporary. He first talks about the controversy that arose after Michel Servet's death at the hands of Calvin, and Castellion's response to it. Castellion deplored the fighting that existed between different religions in the Renaissance. He also thought that punishing a "heretic" led to the magnification of his false doctrine. He believed that Christians should wait for Christ's judgment instead of punishing other Christians based on doctrinal disputes. Castellion also had a spirit of discernment proper to today's way of thinking. Thus, while in many ways Castellion was a man of his time-he agreed, for instance, that blasphemy should be punished by death, and he could not conceive of the complete separation of church and state-he has left his mark on us through his writings.

The final article is written by Pastor Philippe Fromont, and deals with Castellion's De Arte dubitandi. In this rigorous analysis, Fromont tries to establish Castellion's religious epistemology, arguing that, for Castellion, faith is rational and part of knowledge. However, since it contains faith, knowledge consists of a portion that cannot be expressed; knowledge is known through the senses, whereas faith is discovered through testimony. The blind man in the Book of John's ninth chapter believed Jesus first and then saw, and not the other way around. Moreover, salvation depends on faith and therefore cannot be called into question. Faith is not completely communicable, and is only the starting point on the line towards knowledge-which, in turn, is limited by 
faith. In this article, Fromont also talks about how, in Castellion's mind, the scriptures are both interpreted and discovered by reason. Fromont concludes by noting that Castellion's epistemology had the advantage of promoting peace between religious adversaries and of making knowledge an object of individual research.

This collaboration is marked by analytical depth, careful logic, and prudent research. Not only that, but certain authors, like Engammare, show a real eloquence in their writing styles. One might wonder, however, why a book written by four of the best specialists on Castellion has no bibliography-a feature that might have been useful to a student of this Renaissance humanist. Nevertheless, this book is very well thought out and clearly deserves to be read by anyone interested in Castellion.

VIVEK RAMAKRISHNAN

Burlington, Ontario

\section{Essary, Kirk.}

Erasmus and Calvin on the Foolishness of God: Reason and Emotion in the Christian Philosophy.

Toronto: University of Toronto Press, 2017. Pp. xx, 278. ISBN 978-1-48750188-4 (hardcover) \$80.

For many, some of whom ought to know better, "Calvinism" conjurers up the sinners of Jonathan Edwards, the stark walls of churches in Holland stripped of all their ornamentation by rioters in the 1560s, and the burning of Servetus. Likewise, "Erasmianism"-difficult as it is to define-calls up erudition, tolerance, and the humour of Praise of Folly. Kirk Essary begins his book by pointing out that such terms are of no real use, particularly when the two are seen as polar opposites, and by proposing that Calvin's vigorous and forceful judgments against Erasmus should not obscure the deeper agreements between them to be seen in Calvin's reception of Erasmus. A close look at that reception, by way of a side-by-side reading of their interpretations of 1 Corinthians 1:17b27 , suggests that other polar oppositions, chiefly "philosophy vs. rhetoric" and "reason vs. emotion," are equally useless and misleading. Readers of today need to realize that both Calvin and Erasmus shared a humanist conviction 